\title{
Tehran Blues
}

Kaveh Basmenji

London: Saqi Books, 2005. 272 pages.

This informative and timely book, Tehran Blues: How Iranian Youth Rebelled Against Iran's Founding Fathers, is skillfully crafted into eleven chapters that showcase current Iranian politics while drawing insights from its past. Its author, Kaveh Basmenji, was born in Iran in 1961 and is a journalist, translator, and writer. The book's main aim is to explore Iran's presentday youths and their growing disillusionment with the rigid mores of the present regime. Theirs is a generation whose parents rose up against the Shah's excesses and who now feel distanced from the strict religious ideology held by their forbearers of two decades ago. Demanding liberalism and seeking pleasure, the Iranian youths of today are a force to be reckoned with 
and a potential powder-keg of societal instability. Why has Basmenji chosen to focus on them? He answers this question by referring to George Orwell: "Every generation imagines itself to be more intelligent than the one that went before it, and wiser than the one that comes after it."

Through numerous interviews as well as an assessment of contemporary Iran's sociopolitical landscape, Basmenji argues that contemporary Iranian youths are in near-revolt, often openly defying the mullahs and their hardline religiosity. His premise is that Iran's young people are tuning out their Islamic government and are instead embracing an alternative world of private parties, personal weblogs, movies, study, and dreaming about moving to the West.

The book's captivating title is just the start. When one looks through the "Table of Contents," one finds such equally catchy chapter titles as "Dormant Volcano," "Theocracy and Techno," and "A Utopia of Ideas." Perhaps Basmenji's background as a journalist gives him the gift to select attentiongetting headlines that can also serve as a seductive call to the reader. Even the image on the book's front cover is not of an ordinary Iranian youth, but rather of a pensive, cigarette-smoking young woman with a hijab that covers only half of her head and whose non-traditional appearance is a testament to her rebellious nature.

Basmenji begins the book using metaphors from Rumi's Masnavi ("Tale of the Elephant in the Dark"), in which people who touch various parts of the elephant (e.g., its trunk, leg, and ears) describe the creature according to their experience. Thus, each person has an entirely isolated and different understanding from another person who touches the exact same animal. Using this analogy, the author points out that the understanding of the Iranian population among the generations, or even within the same generation, is just as fragmented as it is for the characters in Rumi's tale. The writer also shows how different people's perspectives evolve over time. Some zealous pro-revolutionary militants mellowed as the decades progressed and became less radical and idealistic.

The book is a type of exposé, detailing the hardships that a nation is undergoing and revealing the serial killings of dissidents and freedom fighters. Yet Basmenji masterfully does not bore the reader with a heavy-handed approach, for his prose is never dull or repetitive. Occasionally, however, the book contains run-on sentences. For example, on page 22, the second paragraph consists of only one sentence. In spite of this minor flaw, readers are enticed to immerse themselves in the events of past and present eras. In addition, the quotations chosen for inclusion are brilliant. He taps into a wealth of classical and modern thinkers, philosophers, and politicians and, 
reflecting his international upbringing, draws from both eastern and western cultures.

On a somber note, chapter 9 shows that the power struggle among the reformists and conservatives in Iran is indeed desperate. As the chapter title "Playing Chess with an Ape" suggests, in spite of the fact that in 2000/2001 the reformists made some limited progress in Parliament and municipal councils, the real power remained in the hands of the conservatives. And these people exercised their authority by banning newspapers; imprisoning journalists, students, and political activists; and vetoing any progressive motions made by Parliament, to name just a few actions. As reformed Majles deputy Mohsen Armin stated, it was "like playing chess with an ape."

This book belongs in several categories, such as history or sociology, and can even be considred a lengthy analysis of a social science research endeavor. Due to Basmenji's accessible and engaging writing style, I recommend this book not only to scholars of Persian culture and history, but also to anyone who aspires to be more informed about Iranian society and the chasm between its older and younger generations.

Kaveh Basmenji ends his book on a hopeful note with a quotation from Michael Ignatieff, who, reflecting upon his 2005 trip in Iran, writes: "Though it cannot be much comfort to those who have to live, here and now, under public and private tyrannies, I came away from a night in Isfahan believing that Persian pleasure, in the long run, would outlast Shi'a Puritanism. 